\title{
Praktyczne aspekty opieki nad dzieckiem chorym na atopowe zapalenie skóry: rola współpracy personelu medycznego z pacjentem i jego rodzicami. Obraz kliniczny, rozpoznanie i leczenie
}

\author{
Practical aspects of caring for a child with atopic eczema: the role of cooperation among medical \\ staff and patients and their parents. Clinical presentation, diagnosis and treatment
}

\section{Anna Skiba, Joanna Połomska, Hanna Sikorska-Szaflik, Alicja Woś, Andrzej Boznański, Barbara Sozańska}

I Katedra i Klinika Pediatrii, Alergologii i Kardiologii Uniwersytet Medyczny im. Piastów Śląskich we Wrocławiu Oddział Kliniczny Alergologii Dziecięcej, Samodzielny Publiczny Szpital Kliniczny Nr 1 we Wrocławiu

AUTOR DO KORESPONDENCJ:

Anna Skiba

I Katedra i Klinika Pediatrii, Alergologii i Kardiologii ul. Chałubińskiego 2a, 50-368 Wrocław

tel. 717703091,717703093

e-mail: awskiba@gmail.com

STRESZCZENIE

Słowa kluczowe:

ABSTRACT

Key words:

\begin{abstract}
PRAKTYCZNE ASPEKTY OPIEKI NAD DZIECKIEM CHORYM NA ATOPOWE ZAPALENIE SKÓRY: ROLA WSPÓLPRACY PERSONELU MEDYCZNEGO Z PACJENTEM IJECO RODZICAMI. OBRAZ KLINICZNY, ROZPOZNANIE ILECZENIE

Wprowadzenie. Atopowe zapalenie skóry (AZS) jest chorobą w znacznym stopniu wpływającą na jakość życia chorego dziecka oraz jego rodziny. Zaostrzenia mogą wymagać hospitalizacji.

Cel pracy. W niniejszej pracy pokrótce zapoznajemy czytelnika z jednostką chorobową, jaką jest AZS oraz prezentujemy zgodne z aktualną wiedzą medyczną zasady postępowania z małym pacjentem w trakcie choroby.

Omówienie. Właściwa pielęgnacja skóry dziecka ma obok postępowania farmakologicznego decydujące znaczenie zarówno w opanowywaniu ostrej fazy choroby jak i w trakcie remisji. W celu unikania nawrotów choroby zalecana jest codzienna pielęgnacja skóry z zastosowaniem emolientów. W szczególnych przypadkach zaleca się odpowiednie postępowanie dietetyczne. Ważnym zagadnieniem jest zwalczanie dokuczliwego świądu. Prezentujemy szereg praktycznych, prostych sposobów mogących przynieść ulgę cierpiącym pacjentom. W tym artykule prezentujemy obraz kliniczny i leczenie atopowego zapalenia skóry.
\end{abstract}

atopowe zapalenie skóry, alergia, alergen, atopia, wyprysk

\section{PRACTICAL ASPECIS OF CARING FOR A CHILD WITH ATOPIC ECZEMA: THE ROLE OF COOPERATION AMONG MEDICAL STAFF AND PATIENIS AND THERR PARENIS. CLINICAL PRESENTANION, DIAGNOSIS AND TREATMENT}

Introduction. Atopic eczema (or atopic dermatitis, AD) has a great impact on the quality of life of the affected person as well as the whole family. Hospitalization may be required during exacerbations of the disease.

Aim. The authors of this paper have gathered the essential information about this disease and would like to comment on standards of care and management of atopic dermatitis which are implemented according to the current medical knowledge.

Summary. Applying emollients everyday is a recommended practice for avoiding a recurrence of the disease. Basic skin care is just as important as pharmacological treatment during both the acute and chronic stage. In certain cases, dietary interventions such as food elimination may be beneficial. We present some useful ways for the management of pruritus, which is a disabling feature of AD. In the present paper, the authors discuss clinical presentation and treatment of atopic dermatitis.

atopic dermatitis, allergy, allergen, atopy, eczema 


\section{WPROWADZENIE}

Atopowe zapalenie skóry (AZS, wyprysk atopowy) jest przewlekłą zapalną chorobą skóry, mającą ogromny wpływ na jakość życia chorych i ich rodzin. Przebiega z okresami zaostrzeń i remisji. Jednym z dominujących objawów jest dokuczliwy świąd. Osoby z atopowym zapaleniem skóry mają większe ryzyko zachorowania na astmę, alergiczne zapalenie błony śluzowej nosa i spojówek, alergię pokarmową oraz rozsiane zmiany pęcherzowo-ropne (eczema herpeticum), które są znanym powikłaniem ciężkiego AZS w przypadku zakażenia wirusem opryszczki [1]. Problemem mogą być także zaburzenia snu i depresja [2].

U 60\% pacjentów początek choroby przypada na pierwszy rok życia, u 90\% choroba rozwija się w ciągu pierwszych 5 lat życia. Podczas gdy u większości następuje całkowite ustąpienie objawów wraz z wkraczaniem w okres pokwitania, 10-30\% chorych nadal prezentuje objawy choroby w wieku dorosłym. Jedynie nieliczni zaczynaja chorować jako dorośli [1].

W ostatnich trzech dekadach częstość występowania atopowego zapalenia skóry zwiększyła się w krajach uprzemysłowionych dwukrotnie. Szacuje się, że choruje na nie $10-20 \%$ dzieci oraz 2-10\% dorosłych. Według badania ECAP (Epidemiologia Chorób Alergicznych w Polsce) problem ten dotyczy od 4\% do 8\% Polaków [3].

W patogenezie schorzenia podkreśla się rolę czynników genetycznych, immunologicznych oraz środowiska. Istotą AZS jest zaburzenie funkcji ochronnej skóry poprzez naruszenie jej integralności. Uszkodzenie bariery ochronnej skóry sprzyja przenikaniu mikroorganizmów, czynników drażniących i alergenów, prowadząc do odpowiedzi zapalnej, co skutkuje nadmierną przeznaskórkową utratą wody oraz wyzwala świąd. Próbując ulżyć temu nieprzyjemnemu uczuciu pacjent drapie się, przez co jeszcze bardziej uszkadza skórę i nasila proces zapalny. Powstaje trudne do przerwania błędne koło.

\section{CEL PRACY}

Celem pracy jest zapoznanie czytelnika z jednostką chorobową, jaką jest atopowe zapalenie skóry oraz przedstawienie zaleceń dotyczących właściwej opieki nad dzieckiem w różnych okresach tej choroby i ze szczególnym uwzględnieniem roli jaką ma do odegrania personel medyczny w edukacji pacjenta i jego rodziny. Prezentowane są standardy postępowania $z$ chorym na atopowe zapalenie skóry, zgodne z najnowszymi wytycznymi, stosowane przez personel lekarski i pielęgniarski Kliniki Pediatrii, Alergologii i Kardiologii Uniwersytetu Medycznego we Wrocławiu.

\section{OBRAZ KLINICZNY I ROZPOZNANIE}

Charakterystyczne dla wieku fazy atopowego zapalenia skóry scharakteryzowane zostały w tabeli 1 .
Tab. 1. Obraz kliniczny AZS w zależności od wieku. Zmodyfikowano na podstawie Kurzawa R, red. Atopowe zapalenie skóry. Poradnik dla rodziców. Kraków:Wyd. Help-Med; 2014 [4].

\begin{tabular}{|c|c|}
\hline $\begin{array}{l}\text { Faza atopowego } \\
\text { zapalenia skóry }\end{array}$ & charakter i lokalizacja zmian \\
\hline do 2. roku życia & $\begin{array}{l}\text { zmiany grudkowo-wysiękowe na podłożu rumieniowym, } \\
\text { łatwo ulegające nadkażeniu bakteryjnemu, "polakierowane } \\
\text { policzki", lokalizacja: całe ciało, szczególnie nasilone zmiany } \\
\text { na twarzy, owłosionej skórze głowy, okolica pieluszkowa } \\
\text { wolna }\end{array}$ \\
\hline 2.-12. rok życia & $\begin{array}{l}\text { suchość skóry, zmiany rumieniowo-grudkowe, strupy, } \\
\text { przeczosy, } \\
\text { lokalizacja: zgięcia stawowe dużych stawów (dół łokciowy, } \\
\text { podkolanowy), grzbiety nadgarstków, dłoni i stóp, twarz } \\
\text { wokół oczu i ust, czasem cała powierzchnia skóry }\end{array}$ \\
\hline $\begin{array}{l}\text { okres młodzieńczy } \\
\text { i dorośli }\end{array}$ & $\begin{array}{l}\text { znaczna lichenizacja, liczne przeczosy, nadżerki, krwiste } \\
\text { strupy } \\
\text { lokalizacja: twarz (czoło, wokół oczu i ust), szyja, zgięcia } \\
\text { stawowe, dłonie i stopy }\end{array}$ \\
\hline
\end{tabular}

Rozpoznanie atopowego zapalenia skóry opiera się na stwierdzeniu charakterystycznego obrazu i przebiegu klinicznego choroby. Tradycyjnie wykorzystuje się kryteria Hanifina i Rajki, opublikowane już w 1980 roku. Według najnowszych wytycznych amerykańskich objawy konieczne do stwierdzenia to: świąd, zmiany wypryskowe o typowej dla wieku lokalizacji, które mają tendencję do nawrotów lub występują przewlekle. Istotne objawy to: wczesny wiek wystąpienia zmian skórnych, atopia, suchość skóry. Wśród cech dodatkowych wymienia się nietypowe reakcje naczyniowe (np. biały dermografizm), rogowacenie mieszkowe, łupież biały, pogłębione bruzdowanie dłoni, rybia łuska zwykła, zmiany dotyczące narządu wzroku, zmiany umiejscowione w innych okolicach ciała (np. „naderwanie” płatków uszu), akcentacja mieszków włosowych, obszary zlichenifikowanej skóry, zmiany typu świerzbiączki guzkowej.

W rozpoznaniu różnicowym bierzemy pod uwage świerzb, łojotokowe zapalenie skóry (szczególnie u niemowląt, może współistnieć z AZS), kontaktowe zapalenie skóry, rybią łuskę, chłoniaki pierwotnie skórne, łuszczycę, fotodermatozy [2].

Należy pamiętać, że objawy atopowego zapalenia skóry pojawiają się najczęściej dopiero po $3 \mathrm{mż}$. Jeżeli obserwuje się podobne zmiany u młodszych dzieci, bardziej prawdopodobne jest rozpoznanie dziecięcego łojotokowego zapalenia skóry.

Ciężkość choroby można oceniać za pomocą popularnej skali SCORAD (Severity Scoring of Atopic Dermatitis), Eczema Area and Severity Index (EASI) oraz Patient -Oriented Eczema Measure (POEM) [2]. Najczęściej sięga się po wyżej wymienione skale dla celów naukowych, jako że nie rekomenduje się ich używania w codziennej praktyce. Zamiast tego zbierając wywiad lekarski i pielęgniarski należy zadać szczegółowe pytania o świąd, sen, wpływ schorzenia na codzienną aktywność oraz o przebieg choroby.

Oznaczenia laboratoryjne pełnią pomocniczy charakter w rozpoznaniu oraz monitorowaniu przebiegu choroby. Do tej pory nie udało się ustalić jednego wiarygodnego testu diagnostycznego jednoznacznie sugerującego chorobę lub pozwalającego w sposób wiarygodny monitorować jej przebieg. 
Poziom immunoglobuliny E wzrasta w chorobach atopowych oraz pasożytniczych. Tradycyjnie klasyfikowano atopowe zapalenie skóry na zewnątrzpochodne, gdy obserwowano wzrost stężenia IgE, oraz wewnątrzpochodne, bez takiego wzrostu, który to fenotyp choroby obserwowano u około $20 \%$ pacjentów. U dzieci z podejrzeniem alergii może być pomocne wykonanie oznaczenia stężenia w surowicy alergenowo swoistych IgE (asIgE) lub wykonanie punktowych testów skórnych (skin prick test - SPT) z alergenami powietrznopochodnymi oraz pokarmowymi. Należy pamiętać, że dodatni wynik testów bez obserwowania zależności pomiędzy ekspozycją na alergen, a wystąpieniem objawów alergii, nie jest wskazaniem do jego unikania (np. wykluczenia danego pokarmu z diety). Zarówno oznaczenia asIgE jak i SPT mogą być wykonywane w każdym wieku, jednak u mniejszych dzieci ich wartość jest mniejsza. Przy podejrzeniu kontaktowego zapalenia skóry (np. na nikiel lub niektóre składniki kosmetyków) pomocne są płatkowe testy skórne. Wynik jest odczytywany po 48-72 godzinach. Przeciwwskazaniem do SPT oraz testów płatkowych jest ostre zapalenie skóry, badania te wymagają także odpowiednio wcześniej odstawienia glikokortykosteroidów i leków przeciwhistaminowych, dlatego zwykle diagnostykę odraczamy do czasu opanowania zaostrzenia AZS. W uzasadnionych przypadkach wykonuje się otwartą lub, bardziej obiektywną, ślepą próbę prowokacji pokarmowej poprzez doustne podanie niewielkiej ilości produktu i obserwację reakcji klinicznej. Wiąże się ona z ryzykiem wystąpienia groźnej reakcji anafilaktycznej, przeprowadzenie jej w warunkach oddziału klinicznego zapewnia więc dostępność odpowiedniego sprzętu oraz personelu odpowiednio przeszkolonego do postępowania w nagłych stanach zagrożenia życia [5].

\section{PRZYCZYNY HOSPITALIZACJI}

Przyjmuje się, że atopowe zapalenie skóry jako choroba przewlekła przebiegająca z cyklicznymi remisjami oraz zaostrzeniami powinno być leczone głównie w trybie ambulatoryjnym. Istnieją jednak sytuacje kliniczne oraz diagnostyczne, kiedy hospitalizacja dzieci na Oddziale Alergologii okazuje się niezbędna. Do takich sytuacji można z całą pewnością zaliczyć: ciężkie zaostrzenia, kiedy procesem chorobowym objęte jest ponad $50 \%$ powierzchni skóry, towarzyszy im erytrodermia oraz zmiany wysiękowe, kiedy proces zapalny z miejscowego staje się uogólniony $\mathrm{z}$ objęciem innych narządów (m.in. układ oddechowy, moczowo-płciowy), brak poprawy klinicznej po leczeniu ambulatoryjnym, uniemożliwiające codzienne funkcjonowanie pacjenta [6].

Ponadto w trakcie hospitalizacji możliwe jest nie tylko przeprowadzenie badań laboratoryjnych, ale także obserwacja pacjenta w miejscu wolnym od alergenów i czynników drażniących obecnych w środowisku domowym. W dalszej perspektywie pozwala to na identyfikację potencjalnych alergenów i przyczyn zaostrzeń choroby [7].

\section{LECZENIE}

W skład kompleksowego leczenia atopowego zapalenia skóry wchodzą: wczesna identyfikacja i unikanie czynników drażniących oraz codzienna terapia emolientowa i właściwa pielęgnacja skóry w połączeniu z okresowym leczeniem przeciwzapalnym.

Emolientami (łacińskie „emollire” oznacza zmiękczać) są obojętne biologicznie preparaty do stosowania zewnętrznego, które nie tylko wspomagają leczenie zaostrzeń, ale też stanowią podstawę terapii podtrzymującej AZS [4]. W leczeniu stosuje się tzw. aktywne emolienty, czyli środki zawierające tłuszcze, jak ceramidy, cholesterol, wolne kwasy tłuszczowe, które występują fizjologicznie w warstwie rogowej naskórka. Składniki emolientów podlegają aktywnemu transportowi do cytoplazmy komórek warstw żywych naskórka, tak aby po kolejnych przemianach metabolicznych, wejść ostatecznie w skład płaszcza lipidowego bariery naskórkowej. W atopowym zapaleniu skóry wykazano niedobór poszczególnych tłuszczów warstwy rogowej naskórka, głównie jednak ceramidów, co szczególnie uzasadnia stosowanie preparatów zawierających te składniki [8].

Całkowita terapia emolientowa odbudowuje uszkodzoną barierę naskórkową, ogranicza przeznaskórkową utratę wody, umożliwia utrzymanie odpowiedniego $\mathrm{pH}$ skóry [9]. Obecnie emolienty zawierają w swym składzie wysokonienasycone kwasy tłuszczowe i flawonoidy, które nasilają syntezę endogennych lipidów a także wykazują działanie przeciwzapalne. Regularne stosowanie emolientów zmniejsza zapotrzebowanie na leki przeciwzapalne, w tym na mGKS [8]. Natłuszczanie suchej skóry zmniejsza świąd oraz sprzyja łagodzeniu stanu zapalnego. Nawet jednorazowa aplikacja emolientu przynosi efekt w postaci uszczelnienia naskórka, jednak dopiero systematyczna, kilkutygodniowa terapia przynosi trwałą i zauważalną poprawę jego funkcji barierowej [8].

Aplikacja emolientu na skórę całego ciała powinna odbywać się co najmniej dwa razy dziennie, jednak należy rozważyć dodatkowe dosmarowanie eksponowanych powierzchni ciała, w zależności od indywidualnego zapotrzebowania. Zbyt częsta aplikacja tłustych preparatów opartych na cholesterolu czy wazelinie może podrażniać skórę i nasilać odczuwanie świądu. Rekomenduje się taką terapię u pacjenta, która prowadzi do zużycia minimum 250 g emolientu na tydzień [9].

Emolienty rekonstruują uszkodzoną barierę naskórka i przywracają jego odpowiednie nawodnienie. W tym celu, w skład emolientów oprócz lipidów, wchodzą także takie substancje jak mocznik czy glicerol. Mocznik stosowany w stężeniu 3-10\% wykazuje efekt nawilżający. Należy do substancji naturalnie występujących w tkankach, dlatego nie wykazuje działania alergizującego. Zaaplikowany miejscowo łatwo przenika do głębszych warstw naskórka Jednak ze względu na mechanizm wchłaniania nie należy obawiać się przedawkowania mocznika, gdyż nawet przy przewlekłym stosowaniu na rozległe powierzchnie skóry nie dochodzi do jego kumulacji [4]. Mimo opisanych zalet, wśród pacjentów obserwuje się na ogół lepszą tolerancję glicerolu niż mocznika. U części pacjentów mocz- 
nik wykazuje działanie drażniące, szczególnie przy niewłaściwym zastosowaniu, np na zmiany sączące.

Istnieje szereg istotnych szczegółów, o których należy pamiętać podczas zalecania terapii emolientowej u pacjentów pediatrycznych, np glikol propylenowy łatwo wywołuje podrażnienia i nie powinien być stosowany u najmłodszych dzieci. Ponadto nie należy stosować tych emolientów, w skład których wchodzą wyciągi z orzeszków ziemnych, zwiększające ryzyko uczulenia [8]. U dzieci poniżej drugiego roku życia zaleca się stosowanie emolientów, które są pozbawione białkowych alergenów oraz haptenów [9]. Stosowanie wyłącznie terapii emolientowej na skórę nadkażoną i zmienioną zapalnie jest źle tolerowane i nie pozwala uzyskać poprawy klinicznej. W takim przypadku zaleca się zastosowanie leków przeciwzapalnych oraz dołączenie emolientów wspomagająco $[8,10]$.

Emolienty powinny być dobierane indywidualnie, odpowiednio do sytuacji klinicznej, stopnia suchości skóry, a także zgodnie z preferencjami pacjenta co do zapachu czy konsystencji. Stopień nawilżenia i elastyczność naskórka różnią się w poszczególnych okolicach ciała. Dodatkowo w okresach zimowych skóra jest bardziej sucha i skłonna do podrażnień niż w okresach letnich. Wszystkie te czynniki mogą przekładać się na potrzebę okresowej zmiany rodzaju preparatu czy jego postaci.

Oczyszczanie skóry powinno przebiegać dokładnie i delikatnie, z zastosowaniem środków myjących o odpowiedniej kwasowości (pH około 6). Nie należy stosować mydeł i żeli zawierających detergenty, substancje zapachowe i konserwanty, a raczej delikatne preparaty, tzw. syndety, przeznaczone specjalnie do skóry wrażliwej. Ponadto u dzieci powyżej 12 miesiąca życia należy stosować dodatkowo specjalne szampony [9].

Oczyszczanie skóry w AZS ma znaczenie lecznicze. Najlepszy efekt uzyskujemy poprzez stosowanie krótkiej kąpieli, trwającej do 5 minut, w temperaturze około 27-30 ${ }^{\circ} \mathrm{C}$., z dodatkiem olejków w ostatnich 2 minutach jej trwania. Gorące oraz dłuższe niż 5-10 minut kąpiele są niewskazane, gdyż działają wysuszająco i niszczą naturalny płaszcz lipidowy skóry. Krótkie kąpiele działają nawilżająco, a także usuwają $\mathrm{z}$ powierzchni skóry niektóre alergeny oraz substancje nieswoiście drażniące. Sugeruje się okresowe stosowanie substancji odkażających (np. KMnO4), aby ograniczać kolonizację skóry superantygenem gronkowca złocistego, niespecyficznie nasilającym reakcję zapalną [9]. Sole kąpielowe, poprzez ułatwienie usuwania łusek naskórka, mogą przynosić korzystny efekt w przypadku nasilonego zliszajcowacenia, natomiast dodanie do wanny $1 / 2$ szklanki podchlorynu sodu sprzyja eliminacji świądu.

Substancje takie jak tanina mogą być przewlekle stosowane jako dodatki w procesie pielęgnacji skóry atopowej. Stwierdzono, że nie wchłaniają się po aplikacji, nie wykazują działania ogólnoustrojowego, natomiast przynoszą miejscowy efekt przeciwzapalny, przeciwświądowy, przeciwdrobnoustrojowy i ściągający [8].

Po kąpieli wskazane jest delikatne osuszenie skóry, unikanie tarcia, a następnie szybka, tj do 5 minut od zakończenia kąpieli, aplikacja emolientu. Dla pacjenta pediatrycznego $\mathrm{z}$ atopowym zapaleniem skóry należy wybierać ubranka przewiewne, miękkie, z naturalnych tkanin, jasne, pozbawione barwników, wyprane w delikatnym preparacie i podwójnie wypłukane. Powinno się unikać płukania odzieży w preparatach nadających zapach czy wybielających, a także stosowania odzieży z wełny i innych drażniących włókien i tkanin [4].

W leczeniu zaostrzeń AZS najczęściej stosowane są miejscowe glikokortykosteroidy, które w skojarzeniu emolientami zapewniają znakomity efekt terapeutyczny. Zgodnie z zaleceniem producenta powinny być stosowane raz na dobę, gdyż ich częstsza aplikacja nie zwiększa efektywności leczenia, potęgując ryzyko działań niepożądanych. W celu ich uniknięcia zalecana jest terapia przerywana, polegająca na stosowaniu mGKS tylko przez 2-3 dni w tygodniu, na przemian z emolientami [8].

Udowodniono, że aplikacja mGKS, niezależnie od zastosowania antybiotyku, zmniejsza kolonizację skóry gronkowcem złocistym [8]. W związku z przewlekłą suchością skóry w przebiegu AZS preferowane są mGKS w postaci maści. Wyjątek stanowi obecność zmian sączących, na które zgodnie z zasadami dermatologii należy stosować inne postacie galenowe leku (krem, spray, lotion).

Wobec nieuzyskania oczekiwanego efektu terapeutycznego podczas ambulatoryjnego leczenia zaostrzeń AZS za pomoca mGKS, należy wziąć pod uwagę niezastosowanie się opiekunów dziecka do zaleceń lekarskich, w tym odstąpienie od terapii w obawie przed wystapieniem działań niepożądanych (powszechna fobia steroidowa).

Do alternatywnych opcji terapeutycznych w miejscowym leczeniu atopowego zapalenia skóry należą inhibitory kalcyneuryny (takrolimus, pimekrolimus) należące do grupy leków o działaniu immunomodulującym. Mogą być bezpiecznie stosowane na wszystkie obszary skóry, włącznie z miejscami wrażliwymi, jak twarz, okolice wyprzeniowe czy skóra narządów płciowych [10]. Terapia proaktywna (podtrzymująca) polega na kontynuacji stosowania inhibitora kalcyneuryny po uzyskaniu wygojenia zmian skórnych, w określonych przez lekarza odstępach czasowych, przez kolejne kilka do kilkunastu miesięcy. Takie postępowanie zmniejsza częstość zaostrzeń choroby [11].

Stwierdzono, że już samo leczenie przeciwzapalne za pomocą miejscowych glikokrtykosteroidów, inhibitorów kalcyneuryny czy promieniowania UV zmniejsza kolonizację gronkowcem złocistym. Pomimo tego, stwierdzenie objawów zakażenia bakteryjnego w zaostrzeniu atopowego zapalenia skóry, rozległe wykwity o charakterze rozsianym oraz towarzyszące im powiększenie węzłów chłonnych uzasadniają systemowe zastosowanie antybiotyku [12].

Jako prawdopodobną przyczynę zaostrzenia atopowego zapalenia, należy wziąć pod uwagę możliwość zakażenia wirusem opryszczki zwykłej (herpes simplex virus - HSV), często manifestującej się jako wyprysk opryszczkopodobny Kaposiego, który wymaga systemowego podania leku przeciwwirusowego [8]. 
U wielu pacjentów konieczne jest stosowanie szczególnie cennej opcji terapeutycznej, czyli preparatów recepturowych, których złożony skład, łączący w sobie substancje działające przeciwzapalne oraz przeciwbakteryjne jest dostosowany do konkretnego problemu skóry.

Leczenie systemowe jest zarezerwowane dla ciężkich postaci AZS, nie poddających się terapii miejscowej. Stosuje się wówczas leki immunosupresyjne, w tym glikokortykosteroidy czy cyklosporynę lub leczenie biologiczne.

Wśród opcji terapeutycznych należy wymienić alergenową immunoterapię swoistą (specific alergen immunotherapy - SIT). Najlepiej poznane są efekty kliniczne uzyskane przy zastosowaniu odczulania u pacjentów uczulonych na roztocze kurzu domowego i pyłki roślin [8].

Leczenie dokuczliwego świądu skóry, nierzadko zaburzającego codziennie funkcjonowanie i utrudniającego sen jest wyzwaniem dla lekarza klinicysty. Drapanie się przynosi chorym ulgę, ale przyczynia się do uszkodzenia skóry i sprzyja nadkażeniom bakteryjnym. W niektórych przypadkach staje się przykrym nawykiem emocjonalnym. Należy pamiętać, że świąd niejednokrotnie bywa bardziej nasilony niż wskazywałby na to stopień zaostrzenia choroby. W jego zwalczaniu stosuje się leki przeciwświądowe, leki przeciwzapalne, preparaty natłuszczające i nawilżające - zmniejszające suchość skóry - a także mokre opatrunki. Istotna jest wczesna identyfikacja i eliminacja ze środowiska chorego czynników zaostrzających przebieg choroby, a przez to nasilających świąd.

W leczeniu ogólnym świądu stosuje się leki przeciwhistaminowe pierwszej generacji, jak hydroksyzyna czy klemastyna, które są cenną opcją terapeutyczną szczególnie u pacjentów z zaburzeniami snu. Leki drugiej generacji, jak cetyryzyna czy loratadyna są przydatne u tych chorych na atopowe zapalenie skóry, u których współwystępuje zapalenie spojówek lub alergiczny nieżyt nosa [8].

Zwalczanie suchości skóry jest jednym z podstawowych działań zmniejszających uczucie świądu. Suchość skóry, a przy tym świąd, mogą być nasilane przez liczne substancje, których pacjent $\mathrm{z}$ atopowym zapaleniem skóry powinien unikać. Należą do nich środki myjące i mydła zawierające silnie odtłuszczające detergenty, kosmetyki zawierające alkohol, środki konserwujące, rozpuszczalniki oraz środki zapachowe [4].

Szybki efekt przeciwświądowy można uzyskać poprzez aplikację na suchą skórę emolientu schłodzonego w lodówce. Do tego celu nie są odpowiednie preparaty z dużą zawartością tłuszczu, ponieważ trudno jest je później rozsmarować na skórze [4].

Tzw. mokre opatrunki (wet-wrap treatment - WWT) są przeznaczone dla dzieci z ciężkim atopowym zapaleniem skóry (SCORAD - index ponad 50) [8]. Metoda mokrych opatrunków polega na zastosowaniu dwóch warstw: warstwy przylegającej do skóry, która jest wilgotna, np nasączona emolientem i warstwy zewnętrznej - suchej. Mokre opatrunki wywierają efekt chłodzący, przeciwzapalny, przeciwświądowy. Tworzą barierę ochronną zabezpieczającą skórę przed wpływem czynników środowiskowych a także uniemożliwiają dalsze uszkodzenia skóry wywołane drapaniem.

\section{PIŚMIENNICTWO}

1. Werfel T, Schwerk N, Hansen G, et al. The Diagnosis and Graded Therapy of Atopic Dermatitis. Dtsch Arztebl Int. 2014;111: 509-520.

2. Eichenfeld LF, Tom WL, Cahmlin SL et al. Guidelines of care for management of atopic dermatitis. Section 1. Diagnosis and assessment of atopic dermatitis. J Am Acad Dermatol. 2014;70: 338-351.

3. Samoliński B, Raciborski F, Tomaszewska A i wsp. Wyniki badań programu Epidemiologia Chorób Alergicznych w Polsce (ECAP). Kształcenie Podyplomowe. 2011;3(1): 12-21.

4. Kurzawa R. red. Atopowe zapalenie skóry. Poradnik dla rodziców. Kraków: Wyd. Help-Med; 2014.

5. Lis G. red. Choroby alergiczne u dzieci. Warszawa: Wyd. Medical Tribune Polska; 2013.

6. Sanchez J, Paez B, Macias A, et al. Atopic Dermatitis Guideline. Position Paper from the Latin American Society of Allergy, Asthma and Immunology. Rev Alerg Mex. 2014;3: 178-211.

7. Schneider L, Tilles S, Lio P, et al. Atopic dermatitis: A practice parameter update 2012. J Allergy Clin Immunol. 2013;131: 295-299.

8. Nowicki R, Trzeciak M, Wilkowska A i wsp. Atopowe zapalenie skóry - aktualne wytyczne terapeutyczne. Stanowisko ekspertów Sekcji Dermatologicznej Polskiego Towarzystwa Alergologicznego i Sekcji Alergologicznej Polskiego Towarzystwa Dermatologicznego. Lekarz P0Z. 2015;1: 39-52.

9. Nowicki R, Trzeciak M, Sokołowska-Wojdyło M, Góralczyk A. Leczenie miejscowe atopowego zapalenia skóry. Post Derm Alerg. 2014;XXXI (supl.1): 38-45.

10. Kuna P, Narbutt J, Majak P. Marsz atopowy od AZS do astmy. Czy możliwa jest prewencja?. Dermatol Dziecięca. 2014;4(2): 78-84.

11. Czarnecka-Operacz M. Nowy Algorytm leczenia atopowego zapalenia skóry 0 łagodnym i średnim nasileniu objawów klinicznych: miejscowe stosowanie pimekrolimusu w kremie 1\%. Alergoprofil. 2014;10(4): 5-8.

12. Barańska-Rybak W, Nowicki R. Rola infekcji w atopowym zapaleniu skóry. Post Derm Alerg. 2014;XXXI (1): 20-23.

Praca przyjęta do druku: 14.04.2016

Praca zaakceptowana do druku: 26.04.2016 